\title{
MARCO ANTONIO DE LA PARRA Y LOS GRANDES MITOS CULTURALES
}

\author{
POR \\ MARIO A. ROJAS \\ The Catholic University of America
}

Una nueva dramaturgia estira sus alas Marco Antonio de la Parra

En la dramaturgia de Marco Antonio de la Parra es posible distinguir tres isotopías que entreveradamente atraviesan toda su obra: el mito, el ritual y el poder. Cualquiera de estas tres ondas semánticas que se tome como punto de referencia o de arranque, nos permitirá una visión coherente y globalizante de la escritura dramática del autor. Por nuestra parte, hemos optado por la isotopía del mito, cuya huella seguiremos en tres de sus obras: Matatangos y La secreta obscenidad de cada dia y King Kong Palace. ${ }^{1}$

Nuestra preferencia por el mito no es caprichosa, sino que está respaldada por el mismo dramaturgo quien, en una entrevista reciente, comenta la fuerte atracción que en él ejercen los grandes y pequeños mitos que dibujan el macrotexto de la cultura occidental y que, con los correspondientes ajustes contextuales, se reflejan en los mitos nacionales y cotidianos de la cultura chilena. Al respecto, expresa De la Parra:

Buscar la leyenda: ésa es una cosa que es reiterativa en mi cabeza, insisto mucho en la mitología contemporánea degradada. Se parece al trabajo psicoterapéutico que estoy haciendo, en que lo más trivial es buscar el motivo original: el complejo de Edipo, el primer momento con la madre. Entonces el interés por lo cotidiano, por un mundo no

\footnotetext{
${ }^{1}$ Las ediciones que usamos son las siguientes: Marco Antonio de la Parra, Teatro: Lo crudo, lo cocido, lo podrido, Matatangos (disparen sobre el zorzal) (Santiago de Chile: Editorial Nascimento, 1983). La secreta obscenidad de cada dia, Infieles, Obscenamente (in)fiel (Santiago de Chile: Planeta, 1988). King Kong Palace o el Exilio de Tarzán, Dostoievski va a la playa (Santiago de Chile: Pehuén, 1990). Sobre estudios de otras obras del autor no tratadas aquí, ver el excelente artículo de José R. Varela, "Lo circunstancial, lo histórico y lo recurrente en Lo crudo, lo cocido y lo podrido" de Marco Antonio de la Parra: ensayo de análisis integral", Revista de Estudios Hispánicos, I (otoño 1990) 81-109. Catherine M. Boyle, Chilean Theater, 1973-1985: Marginality, Power, Selfhood (Rutherford: Fairleigh Dickinson University Press, 1992). Ver en especial 58-117; 178184 donde la autora se refiere a Lo crudo, lo cocido y lo podrido y a Toda una vida. Tanto Varela como Boyle utilizan la versión de Lo crudo ... aparecida en Teatro Chileno de la Crisis Institucional: 1973-1980, ed. Hernán Vidal, María de la Luz Hurtado y Carlos Ochsenius (Minneapolis/Santiago de Chile: Minnesota Latin American Series/CENECA, 1982).
} 
mágico en sí, al estilo de los realistas o los minimalistas, sino en cuanto restos del mito. Siempre ando buscando las huellas del dinosaurio, de un relato legendario que me produce una fascinación infantil. El ser un relator de estos mitos me enloquece. ${ }^{2}$

Aclaramos, además, que nuestro objeto de estudio será de preferencia el texto dramático/literario, el cual asumiremos, sin embargo, como una virtual puesta en escena, teniendo siempre presente la descodificación de su doble referente, que comprende tanto el mundo imaginario que evoca su lectura (de modo similar a cuando leemos una novela), como el mundo imaginario escénico de la representación. ${ }^{3}$ Esta opción por el texto literario está también en consonancia con la dramaturgia postulada por De la Parra, para quien, a diferencia de la posición de muchos teatristas contemporáneos, la palabra, o código verbal (y por tanto el texto literario) tiene un valor fundamental. La nueva dramaturgia, afirma De la Parra, debe siempre buscar "[un] manejo del lenguaje que convierta las palabras en joyas que el trabajo escénico ilumine y a la vez deslumbre a su portador de siempre, el actor". Insistiendo en este pensamiento concluye: "Ya no se puede hablar como antes sobre el escenario. No hay lugar donde pesen más las palabras. Tal vez un altar. Tal vez, ya ni siquiera". ${ }^{4}$

\section{MATATANGOS (DISPAREN SOBRE EL ZORZAL) Y EL MITO GARDELIANO}

Desde su trágica muerte ocurrida el 24 de junio de 1935, el popular cantante de tangos, Carlos Gardel, ha sido motivo de numerosas biografias y otros tantos textos de ficción, que aumentaron más aun al conmemorarse los cincuenta años de su muerte. Además de la gran popularidad del cantante, lo que más ha intrigado y despertado el interés de los escritores son los enigmas y los muchos mitos existentes en torno a su figura. De la Parra -el mitólogo/mitógrafo- no deja pasar esta gran oportunidad y escribe una original obra, en la cual se revela como un profundo conocedor de la mitología gardeliana, que lúdica y paródicamente desmitifica y remitifica.

Las didascalias con que se inicia Matatangos requieren de una atenta lectura porque, prospectivamente, anticipan una serie de rasgos que caracterizarán la composición y semiosis de la obra. Estas didascalias piden, antes del despliegue de las cortinas y en apagón total de luces, la emisión de sonidos que provienen de distintas fuentes y tiempos: los punteos iniciales del tango "Muñeca brava", la voz de Louis Armstrong, el popular cantante negro; avisos comerciales provenientes de la televisión, un grito de mujer de una película de terror, una final de hípica y una descarga de artillería (95). Los signos de estas acotaciones son importantes porque, en la materialidad fónica de sus significantes, converge una pluralidad de significados que aluden a distintos aspectos de la vida de Gardel: su papel pionero del tango cantado, su afición a las carreras de caballo, su paso de galán por el cine,

${ }^{2}$ Marco Antonio de la Parra/María de la Luz Hurtado, "El nuevo teatro chileno", La Escena Latinoamericana, 3 (diciembre 1989) 38.

${ }^{3}$ A propósito de este doble referente seguimos la posición teórica de Jean Alter. Véase su $A$ Sociosemiotics Theory of Theatre (Philadelphia: University of Pennsylvania Press, 1990). Ver en especial 176-177.

4 "Para una nueva dramaturgia", Apuntes, 104 (invierno-primavera 1992) 85. 
en fin, su papel fundacional en la creación de un estilo de música que rápidamente se incorporaría como esencial componente de la cultura popular no sólo argentina sino latinoamericana -influencia similar a la que ejerció Louis Armstrong en los Estados Unidos. Todos estos temas irán apareciendo a lo largo de la obra. Estas didascalias reflejan también la concepción posmodernista del texto, rasgo que se observa, especialmente, en el uso del pastiche y collage, y en el fundido de tiempos en que se reúnen textos, aparentemente dispares e inconexos, provenientes de distintos momentos de la historia. En las didascalias, además, tanto el grito de terror de la mujer como la descarga de artillería, anticipan otro rasgo notorio de la obra, que en su inocente ludicidad, oblicuamente, lanza destellos, señales que se refieren al contexto chileno, a la dictadura vigente en el tiempo de la enunciación tanto escritural como escénica de la obra, señales que no pudieron pasar desapercibidas por el receptor/espectador de entonces.

La acción de Matatangos no sigue una linealidad convencional sino que avanza en espirales de sucesivos círculos. Todo tiene lugar en el sótano de un hotel de Medellín donde, supuestamente, se alojó Gardel la noche anterior al fatal accidente aéreo que lo condujo a la muerte. Tres de los guitarristas que lo acompañaban, "maquillados de tal forma que parecen la imagen misma de Gardel sacada de una revista de época" (95), se preparan para realizar un ritual. Uno de ellos será elegido para actuar de ("jugar" el papel de) Gardel para lo cual "cargan la mata", que es un modo con que se elige en un juego de niños a aquél del grupo que se convierte usualmente en un sometido al poder de los demás participantes. DOS resulta elegido como el principal ejecutor del papel del ídolo, que lejos de ser aquí un privilegio es más bien un infortunio ya que deberá someterse a un continuo asedio y a reactuar escenas poco gratas del pasado del cantante. Los guitarristas UNO y $T R E S$, por su parte, desempeñarán distintos personajes relacionados con Gardel: su madre, amigos (Razzano, por ejemplo), el médico que le hizo la cirugía estética, jueces, prostitutas, nazistas, etc. Se da comienzo así a un ritual, pulsionado y demarcado internamente por las muertes sucesivas de $D O S$, que son ocasionadas por el disparo de un revólver que, precisamente, configura la estructura de espiral a que aludíamos anteriormente. En este "aire ceremonioso, de ritual secreto, de misa negra" (95) los cantantes/actores parecen seguir un libreto que, como el de una obra de teatro, debe ser respetado sin alteraciones "Nunca un juego es un juego si las reglas no son cumplidas", dice uno de los personajes (124). Sin embargo, el libreto del metateatro parece alterarse constantemente, sobre todo en ocasiones en que las acciones del presente y pasado y los niveles de ficción se obliteran al punto que no sabemos si la violencia de los guitarristas UNO y TRES es ejercida sobre Gardel, es decir, sobre el personaje representado, o sobre DOS, el actor. De esta manera a través de un movimiento especular, metateatral, se construirán, con el soporte argumental de letras de tango, de escenas de películas, y diálogos supuestamente enunciados por interlocutores en el pasado, distintos momentos de la vida de Gardel y se procederá al desmontaje de su mitología. Se desmantelará el signo Gardel (todo mito es un signo de signo nos remarca Barthes $^{5}$ ), se le despojará de todos sus significados connotativos, algunos

\footnotetext{
${ }^{5}$ Roland Barthes, Mitologias, $4^{\mathrm{a}}$ edición (México: Siglo XXI, 1983). Para una comentario y revisión de la definición de Barthes, ver Nun Gertz, "Social Myths in Literary and Political Texts", Sociocriticism 2/6: 37-61; Sandor G.J. Hervey, Semiotic Perspectives (Boston: Allen \& Unwin, 1982) 139-148.
} 
de los cuales fueron creados por el propio Gardel (narcisismo común de las grandes estrellas) $\mathrm{y}$, otros tantos, por la propaganda comercial o por motivaciones ideológicas o políticas. La excesiva acumulación de significados hace que la figura-signo-mito explote en una pirotecnia semántica ambivalente y contradictoria, en que la verdad se confunde con el engaño, y lo inventado con lo real. El Gardel de Matatangos se desconstruye/reconstruye, precisamente, a partir de todas estas ambivalencias y contradicciones que empiezan con el nacimiento mismo del cantante y que se extienden hasta su muerte: ¿Quiénes fueron sus verdaderos padres? ¿Nació realmente en Toulouse, en Tacuarembó o en Buenos Aires? ${ }^{6}$ ¿Tuvo o no una historia prontuaria? ¿Cuáles fueron sus relaciones con el sexo opuesto? ¿Es realmente el ideal de macho que se proyecta en sus tangos y películas? ¿Qué tipo de relación mantuvo con sus amigos (en especial con José Razzano, con quien formó un dúo de mucho éxito y que debió abandonar su carrera justamente cuando Gardel empezaba a adquirir fama y buscaba independizarse como solista? ${ }^{7}$ ¿Se aplicó la cirugía estética y, si lo hizo, en qué consistió la operación? ¿Fue el accidente, que lo llevó a la muerte, casual o premeditado? Todos estos vacíos fueron llenados por sus admiradores con el rumor y la conjetura, la alucinación y el deseo y, retóricamente, mediante una traslación metonímica: Gardel es el tango; Gardel es el ideal del porteño. En Matatangos el proceso de desmitificación se hace mediante una técnica similar a la focalización interna empleada en un texto narrativo. En efecto, no se realiza a partir de la omnipotencia del dramaturgo básico, ${ }^{8}$ de su control e interpretación del mundo ficticio, sino desde los personajes mismos (UNO, DOS y TRES), que son los que construyen e interpretan el mundo. Contrariamente a lo que se esperaría, UNO y TRES manifiestan una franca antipatía hacia Gardel, a quien hostigan sistemática e impíamente, con sádica fruición, despojándole de cada una de sus vestiduras míticas y exponiéndolo en toda su desnudez, con todos sus defectos y debilidades: su gordura, la ambición que lo lleva a abandonar su público por la platea de millonarios, el cuestionable afecto hacia su madre, de quien se preocupa esmeradamente para proveerla de todo lo que necesita, pero con quien nunca quiso fotografiarse, la cursilería y clichés de

\footnotetext{
${ }^{6}$ Aunque la mayoría de los biógrafos dan como seguro el nacimiento de Gardel en Toulouse, Francia, hay algunos que cuestionan tal filiación. Éste es el caso, por ejemplo, de Blas Matamoros, quien en su "San Gardel, comediante, mártir", aparecido en Le Tango: Hommage à Carlos Gardel (ToulouseLe Mirail, 1985). El mismo Matamoros comenta las hagiografia gardelianas. Una de ellas que dice que era hijo de un noble francés y de una oscura planchadora (ésta es la versión folletín rosa); otra (el folletín negro) es la de la cuna pobre, del vagabundo que crece en una "zona tenebrosa de la capital" (17). En Matatangos, cada cantante presenta una de las tres versiones existentes: "UNO: Mi nombre es Carlos Romuald Gardés, hijo de padre desconocido y Berthe Gardés, planchadora, obrera francesa, militante de la juventud católica de Tolosa ... DOS: (Interrumpiendo) Mi nombre es Carlos Gardel y nací en Tacuarembó ... TRES (Interrumpiendo) Mi nombre es Carloto Emilio Gardenia y nací en la gran capital federal de Buenos Aires ..." (101-102).

${ }^{7}$ Por muchos años Razzano formó un dúo con Gardel hasta el momento en que, por una afección incurable a las cuerdas vocales, Razzano debe retirarse. Luego fue agente de Gardel y finalmente despedido de la tarea por éste.

${ }^{8}$ Sobre esta categoría véanse: Juan Villegas, Nueva interpretación y análisis del texto dramático (Ottawa: Girol, 1991) y Michael Issacharoff, Le Spectacle du discours (París: Librairie José Corti, 1985).
} 
sus tangos, el agridulce folletín con que el propio Gardel se fabrica su vida. Es decir, se despoja al signo-mito-Gardel de sus significados connotativos para revelarlo en su pristina denotación. ${ }^{9}$ De este modo, en su desmitificación, los guitarristas adoptan un punto de vista y un recorrido diametralmente opuesto al de los admiradores y creadores del mito. ${ }^{10}$

Matatangos es un texto autorreflexivo, pero, a diferencia de otras metaficciones, no es un texto que narcisistamente se revierta sólo a sí mismo, sino que constantemente se proyecta a una realidad tangible, a la dictadura chilena, que apenas se roza (una prudencia necesaria). Sin embargo, la intención del autor no es ni didáctica ni de directa apelación al contexto histórico social, sino que prefiere más bien la alusión indirecta. Al respecto, basta sólo un ejemplo. El siguiente diálogo, aunque se refiere a la situación que vivía el mundo occidental en tiempos de Gardel, a la gran depresión económica de la cual unos pocos se enriquecieron a costa de la explotación de una gran masa famélica y cesante, y al advenimiento del nazismo que ya empezaba a manifestar su ominosa presencia, puede igualmente analogarse con la situación chilena del momento:

TRES: No llorés, todos hemos hecho cosas peores.

UNO: Hemos matado, delatado, robado, inculpado injustamente.

TRES: Es el destino del siglo, reinan los ciegos, criminales lanzan las naciones a la guerra, locos ocupan las tribunas. (136)

A continuación reproducimos la didascalia que da cierre a la obra, para desprender de ella algunas conclusiones finales.

(Ruido de aeropuerto por los parlantes. Muy suave. Parodian la subida del avión mientras emerge el sonido de "Rubias de New York", foxtrot grabado por Gardel, la música acompaña los fogonazos, la subida al avión, la despedida. Se sientan. Uno suavemente saca la pistola. Sentados tras Dos. Tres y Dos bromean. Uno apunta. Dos, en un chiste, se da vuelta hacia Uno. Mira la pistola con horror. Uno dispara en el preciso momento

\footnotetext{
${ }^{9}$ La oposición victimario/víctima, torturador/torturado que se establece entre UNO/TRES y DOS, no es totalmente cristalina, pues en muchas instancias se percibe en DOS un cierto masoquismo, una complacencia ante el sadismo de UNO y TRES: TRES.-iVas a morir de todas maneras Charloto! (lo arroja)/ DOS (molesto). -Prefiero ... demorarme un poco ..." (99).

${ }^{10}$ Donald Castro, en "Popular as a Source for the Historian: Why Gardel?", Studies in Latin American Popular Culture Vol. 5 (1986) 144-162, a propósito de la persistencia del mito gardeliano, sostiene que la razón principal de este fenómeno es que el mito Gardel está íntimamente vinculado al ídolo o mito folklórico porteño (del cual Gardel sería el prototipo por excelencia) y que es definido con los siguientes rasgos: "Debe ser un macho, demostrar fidelidad y lealtad, forjarse un bienestar material, y demostrar un sentido de alienación/vulnerabilidad" (154). Castro proporciona datos en la biografía de Gardel que parecieran confirmar esta vinculación. Matamoros en el ensayo citado (ver nota 6) afirma algo similar: "En resumen, la santidad laica de Gardel está justificada en una sociedad como la argentina de su tiempo, pues Gardel encarna los ideales triunfantes de desclasamiento y ascenso social de vastas capas de dicha sociedad, que, en algún momento $u$ otro, pasan por el amplio y borroso campo de las clases medias. En las orillas de su persona están las dos pendientes que llevan del medio pelo hacia arriba, hacia abajo, los abismos de la marginalidad" (40). Vale hacer notar, sin embargo, que la visión de Matamoros es definitivamente desmitificadora.
} 
en que el disco se pega en una raya y se queda repitiendo una frase una y otra vez. Cae Dos en cámara lenta. Uno se persigna, Tres se tapa la cara. La luz se apaga. Queda el disco rayado sonando un instante hasta que se escucha que alguien, con violencia, saca el brazo del tocadiscos) (157).

Lo remarcamos una vez más: (1) Todo mito es un signo. (2) Mediante un proceso de semantización cualquier objeto puede crear y preservar mitos (piénsese en la propaganda comercial). (3) Todo mito se construye a partir de un signo primario (significante/ significado) sobre el cual se edifica el signo mítico mediante la acumulación de significados (artificiales) connotativos. (4) Este proceso da como resultado un mensaje sin código, es decir, una mascarada como algo natural. Como bien lo señala Hervey, "En esta subversión de relación y diferencia entre lo natural radica el corazón de todo mito" (140). A nuestro parecer, esta teoría sobre el mito está maravillosamente resumida en las didascalias recién citadas, las cuales, irónicamente, sintetizan a su vez todo el juego teatral, la ludicidad de la obra, su tesitura paródica. En su proceso de desmitificación, la obra acaba aniquilando el último rasgo, el esencial, del mito-signo Gardel, que es su voz. Se trata de un golpe definitivo y certero: se acaba con lo que sustentaba el mito: su materialidad lingüística. $\mathrm{El}$ acto violento con que se saca el brazo del tocadisco, refleja, retrospectivamente, la violencia de la desmitificación que han ejercido $U N O$ y TRES a lo largo de la obra.

Pero, bien lo sabemos, la voz es lo único sensible que nos queda de Gardel (del signo primario denotativo), que es indestructible y que sigue manteniendo la popularidad y perdurabilidad del mito. La obra concluye con la paradoja de toda desmitificación: inversamente se dibuja la remitificación. Esta paradoja es signada en las didascalias que comentamos en la alusión que se hace del accidente aéreo, en que el autor retoma la leyenda mítica: que murió por un disparo, versión que precisamente en la obra había sido desmitificada." En el fondo, tal como dice Juan Andrés Piña, a pesar de la irreverente desconstrucción del mito gardeliano que hace De la Parra, hay en él "un reconocimiento implícito, casi cariñoso a Gardel". ${ }^{12}$

\section{LA SECRETA OBSCENIDAD DE CADA DIA Y LA DESMIFICACIÓN DE DOS}

Metadiscursos de la época moderna

CARLOS: ¡Me carga su vitalismo retrógrado, señor Freud!

\footnotetext{
"Refiréndose a un incidente que tuvo Gardel en su juventud en que fue baleado, los guitarristas parodian la escena pasada, pero a su vez aluden al futuro del accidente aéreo: "TRES: Saquémosle la bala ... como los cowboys, con un cuchillo rojo. UNO: No. TRES: ¿No?. UNO: La bala servirá para el crimen. TRES: ¿Cómo? UNO: Confundirá a los legistas. TRES: (Parodiando voz de anciano médico): Hemos encontrado esta bala en el cuerpo carbonizado del extinto; sospechando corresponde a la causa de muerte del occiso", 115-116.

12 Juan Andrés Piña, "Marco Antonio de la Parra: El teatro del ritual y del derecho". El Teatro: Lo crudo, lo cocido, lo podrido, Matatangos (disparen sobre el zorzal) (Santiago de Chile: Editorial Nascimento, 1983) 22.
} 
SIGMUND: ¡Lo que es a mí me tiene hasta la coronilla su racionalismo decimonónico, señor Carlos Marx! ¡Míreme! ¡Mírese! ¡Nos han convertido en caricaturas! ¡En seres obscenos! ¡Obscenos!

A propósito de esta obra, Bernardo Subercaseaux expresa el siguiente juicio: "Marco Antonio de la Parra en La secreta obscenidad de cada día (1984) sitúa a Marx y a Freud los dos 'santones' de la época moderna- en función de voyeristas: divertimento irónico pero también alusión a la crisis de autoridad del racionalismo y de la cultura ilustrada de Occidente" (138). ${ }^{13}$ Esta afirmación parece ajustarse más bien a la lectura del texto escrito, el cual desde el principio nombra a los personajes de la obra como Carlos y Sigmund, que el lector puede o no (según sea su perspicacia y competencia cultural) asociar con Marx y Freud. En lo que respecta al texto espectacular, el público identifica a los personajes como tales sólo hacia la mitad de la obra, en el momento en que los exhibicionistas pretenden ser (o actúan como) Marx y Freud. Sin embargo, la presencia e intensidad dramática de este segmento, sus implicaciones ideológicas, la polémica recepción que generó en los foros posteriores a la representación y, sobre todo, la gran atención que ha puesto en él la crítica, hacen que esta parte, a modo de una sinécdoque, se proyecte a toda la obra, absorbiéndola ${ }^{14}$

¿Qué modalidad teatral emplea De la Parra en su cuestionamiento posmoderno (seguimos a Subercaseaux) de estos dos grandes metadiscursos culturales? Evidentemente, la convención realista, unívoca y directa, lógica y lineal, habría sido la opción más eficaz para el planteamiento y desarrollo de un conflicto dramático generado a partir de polarizaciones ideológicas. Sin embargo, como en Matatangos, el dramaturgo prefiere el descentramiento y fragmentación de la fábula, la plurivalencia y ludicidad metaficticia y el doble código paródico, recursos que en concertada complicidad, esquivan, aplazan, o desplazan todo argumento definitivo, conduciendo al receptor a una lectura equivocada de los significantes $\mathrm{y}$, consecuentemente, a una falsa descodificación.

La obra se inicia con el encuentro casual de dos individuos vestidos como exhibicionistas que esperan en una plaza, frente a una escuela, la salida de las escolares para realizar su acto impúdico. Esta situación inicial sugiere un atractivo conflicto dramático que aguijonea la curiosidad (¿la secreta obscenidad?) del espectador, que seducido y capturado por esta línea isotópica, la sigue con vivo interés, sin fijarse en los abundantes signos prolépticos diseminados a lo largo de todo el texto, que de ser descodificados oportunamente (como en los cuentos de Cortázar), harían el final menos sorpresivo. La acción, volátil y esquiva, no progresa en dirección hacia el desenlace esperado (¿deseado?) sino que, como en Matatangos, se va distendiendo en forma de espirales o juegos metateatrales, que obstruyen y retardan, como el oponente actancial greimasiano, el punto

\footnotetext{
13 "Nueva sensibilidad y horizonte 'post' en Chile (Aproximaciones a un registro)". Nuevo Texto Crítico 6 (Segundo semestre de 1990) 135-145.

${ }^{14}$ Tal fue el caso en la discusión que siguió a la puesta realizada por el Grupo Gala en Washington DC, como parte del Congreso de Teatro Latinoamericano organizado por el IITCTL y The Catholic University of America en junio de 1990, en que se desató una gran polémica en torno a estos dos personajes, en especial en relación a Carlos.
} 
de llegada. En estos juegos los "exhibicionistas" pasan por una serie de mutaciones: policías secretos, torturados/torturadores, Marx, Freud, payasos de circo, vendedores ambulantes, borrachos de esquina, cuidadores de auto, vendedores de paraguas, etc. Con esta simulación se persigue, en un nivel de lectura superficial, burlar la vigilancia policial y, en otro más profundo, revivenciar, como en una sesión psicoanalítica, algunos fantasmas traumatizantes del pasado que es necesario exorcizar; fantasmas que más que de la memoria personal son parte de la memoria colectiva. Al mismo tiempo que se desafia y se desmonta el discurso oficial monovalente, que impuso una "política del olvido", se le responde con la "reivindicación de la memoria". 15

De todos los metateatros, como lo señalábamos más arriba, el que se impone, por su duración e intensa carga ideológico-emocional, es el de Freud y Marx, representantes de dos discursos dominantes del pensamiento y acción de la cultura moderna, que desde el tiempo de su enunciación se han ido recubriendo de mitos, se han degradado, transformado en tópicos o en instrumentos de represión y destrucción.

Las espirales o juegos metaficticios constantemente se trasvasan, dando paso a niveles de fícción en que no es fácil diferenciar el continente del contenido, el marco de lo enmarcado. Esta ambigüedad y polisemia ha llegado a confundir hasta a los mismos críticos. Así, entre éstos, hay algunos que sostienen que el grado de conocimiento que el receptor tiene del mundo desplegado en la obra es superior al de los personajes (situación que es típica de las comedias de enredo). ${ }^{16}$ Sin embargo, un examen cuidadoso del texto revela que desde un comienzo Carlos y Sigmund saben que están allí no para exhibirse, sino para ejecutar un plan bien preciso: el asesinato de algunas autoridades de gobierno. Lo que ambos personajes tratan de hacer, desde su imprevisto encuentro, es averiguar la razón de esta coincidencia, de descubrir las intenciones del otro, de medir el peligro que implica su presencia y de sopesar el riesgo y consecuencia de una participación conjunta en esta misión tan peligrosa. Al comienzo mismo de la obra, Sigmund pregunta a Carlos: "¿Usted ... tiene una niña en este colegio?" Carlos, que quiere ir directamente al grano, secamente replica: "Hace mucho rato que debe haber comenzado la ceremonia, ¿O no?" (59). Está claro que Carlos no quiere participar en el juego de disimulo, de indirecta pesquisa que le propone Sigmund. Su resistencia, sin embargo, dura poco. A la pregunta de Sigmund de

${ }^{15}$ A propósito de los mecanismos discursivos de la dictadura y las respuestas contestarias de los artistas, véase Daniel Balderston, et al., Ficción y política: La narrativa argentina durante el proceso militar (Buenos Aires: Institute for the Ideologies and Literatures, Alianza Editorial, S.A., 1987). La cita corresponde al artículo de Beatriz Sarlo, "Política, ideología y figuración literaria" 33.

${ }^{16}$ Véase, por ejemplo, de Catherine M. Boyle: "La obra dramática de Marco Antonio de la Parra, o la representación de un juego hamletiano", Alba de América 12 y 13 (julio 1989) 145-150. Dice la autora: "Metidos en una realidad aparte, los protagonistas no tienen la visión desde afuera que tiene el público, no tienen acceso a las claves esenciales como para identificarse el uno al otro" (149). En cambio, Eduardo Thomas, "Ficción y creación en cuatro dramas chilenos contemporáneos", Revista Chilena de Literatura 33 (1989) 61-70, parece más coincidente con mi interpretación cuando sostiene: "[los personajes] avanzan en su relación desde el simple deseo de averiguar sobre el otro para efectos de la seguridad personal, hasta el goce lúdico de exhibirse uno a otro sus recursos de enmascaramiento" (67). 
por qué lleva puesto sólo un impermeable, Carlos finalmente se somete a los términos impuestos por Sigmund:

CARLOS: Sí, bien, verá ... lo que pasa es que tuve un accidente. Los pantalones se me rasgaron ...

SIGMUND: (con placer) ¿En el entrepiernas?

CARLOS: (risitas cómplices) Como una sandía.

El bien (el énfasis es nuestro) equivale a "acepto el juego". Y, precisamente, es a partir de este momento que se desata el teatro dentro del teatro. Otra clave viene muy luego. Cuando Carlos le muestra a Sigmund su arma ("una magnum o una parabellum, grande y potente", lo sabemos después, (123)) se entabla el siguiente diálogo:

SIGMUND: ¡Dios mío! ¡Usted exagera!

CARLOS: Es impresionante, ¿No le parece?

SIGMUND: Y lo disfruta ... ¡Es excesivo, diría yo!

CARLOS: ¿No lo asusta? ¿No es cierto que es impactante?

Se deslizan aquí dos claves lingüísticas, dos significantes de ambivalente significado que previenen al receptor que el referente que él tiene en mente no es aquél al que se dirigen los personajes. Inmediatamente después, cuando Carlos imprudentemente lanza una comprometedora palabra que los puede delatar, y desbaratar sus planes, Sigmund replica suspendiendo el juego momentáneamente:

SIGMUND: ¡Es redundante, a decir verdad! ¿Para qué ... tanto? ¿Ah ... usted parece que lo único que quiere es que se fijen en su gran ... gran ... gran ...

CARLOS: ¡Mi gran cañón!

SIGMUND: iSilencio! iRealmente usted parece querer que nos atrapen! ... (82) (el énfasis es nuestro)

El texto está lleno de señales que indican que el juego metaficticio no es tan simple, que la historia en torno a los exhibicionistas no es la historia en primer grado, sino que, como se revela al final, no es más que otra pieza en el interior de una caja china. Pero el lector/ espectador aferrado a lo obvio inocentemente cae en las trampas del texto "traidor y maletero", ${ }^{17}$ como lo describe el mismo De la Parra. Sólo el sorpresivo impacto final le reordena su visión, imponiéndole una espeluznante rectificación semántica, emocional e ideológica, que es metafóricamente equivalente al impacto de las balas. ${ }^{18}$ Lo cómico, lúdico y ambivalente violentamente se le torna serio, terrible e inequívoco.

\footnotetext{
17 “Obscenamente (in)fiel" 41.

${ }^{18}$ Es interesante destacar que el lugar de la salida de los políticos se supone está detrás de la platea y las armas de fuego se apuntan al público, lo cual produce un efecto aun más impactante.
} 
¿A qué se debe esta predilección de Marco Antonio de la Parra por el uso de signos teatrales plurivalentes y por la traslación metafórica? ¿Se trata de la criticada indiferencia del discurso posmoderno por "aprehender algún sentido" y que el autor más bien "prefiere jugar hasta el infinito con la polisemia y ambigüedad de los signos en desmedro del significado"? ¿Está más interesado en la materialidad significante de los signos que en su significación? ${ }^{19}$ Veamos dos respuestas al respecto. ${ }^{20}$ La primera sostiene que estas preferencias fueron "condicionadas por factores de orden histórico, social, político y cultural". ${ }^{21}$ Toda la generación de De la Parra se vio obligada a autocensurarse, a escribir en claves, a utilizar "un lenguaje de doble y triple sentido", ${ }^{22}$ a "poner cuidado en el decir y en el cómo decir" con el fin de desafiar, y contrarrestar el discurso oficial. ${ }^{23}$ Sin embargo, esta tendencia estética se ha intensificado en toda Latinoamérica, a pesar del retorno de la democracia, lo cual vendría a apoyar la posición de que se trata más bien de un movimiento estético/cultural (la posmodernidad) que va más allá de la contingencia histórica. Entre los chilenos que adoptan este punto de vista, se encuentran María de la Luz Hurtado y Juan Andrés Piña. ${ }^{24}$ Refiriéndose a estos jóvenes, Hurtado comenta: "Son las generaciones jóvenes las que se resisten a reproducir pensamientos elaborados por la política o el discurso causal. Optan por adentrarse en las emociones, sensaciones, imágenes, contradicciones, trastornos que hacen esa realidad múltiple e impredecible, que confunde a unos y otros

\footnotetext{
${ }^{19}$ Magaly Muguercia, "Lo antropológico en el discurso escénico latinoamericano", Conjunto 85-86 (octubre 1990-marzo 1991) 17.

${ }^{20}$ En realidad habría una tercera respuesta, una personal dada por el mismo autor, quien nos habla de su afición a la ambigüedad en los siguientes términos: "Nada es tan imantador para mí como lo ambiguo, lo doble, lo conflictivo. Detesto los maniqueísmos, las claridades, las definiciones ... El ave fénix es para mí el único pájaro posible y sólo las antagonías me sefialan los caminos del encuentro. La ambiguledad me parece el requisito de todo pensamiento". Y es precisamente esta atracción por lo ambiguo que le lleva a elegir como personajes a Marx y Freud: "Marx y Freud me eran queridos y temidos, odiados y extrañados, y esa ambiguedad me atraía, como la luz a las polillas: "Obscenamente (in)fiel: o una personal crónica de mi prehistoria dramatúrgica". En $L a$ secreta obscenidad de cada día (Santiago: Planeta, 1988) 39. La búsqueda de la reconciliación o neutralización de contrarios es uno de los rasgos que se atribuyen al paradigma posmoderno.

${ }^{21}$ Senela Millares y Alberto Madrid, "La última narrativa chilena: la escritura del desencanto", Cuadernos Hispanoamericanos, 492-83 (agosto-septiembre 1990) 116. Aunque los autores se refieren a textos narrativos, su comentario es igualmente aplicable al texto dramático.

${ }^{22}$ Grinor Rojo, Muerte y resurrección del teatro chileno 1973-1983 (Madrid: Ediciones Michay, S. A., 1985) 50.

${ }^{23}$ Ésta es la posición de Thomas, quien afirma lo siguiente: "En el mundo dramático de La secreta obscenidad de cada día, la dimensión enmascarada de la ficción se justifica por la presencia de un medio social violentamente represivo. La máscara tiene por finalidad protegerse de la acción represiva ... la palabra ... abre el acceso a la memoria, al recuerdo, a la comprensión profunda de la realidad histórica y contingente del espectador. Aquí la palabra artística es subversiva: se erige como un atentado contra el poder represivo; es un instrumento de liberación. Actúa sobre el espectador con violencia desmitificadora, porque, en esencia, es un acto exhibicionista y transgresor. "Ficción y creación en cuatro dramas chilenos contemporáneos", Revista Chilena de Literatura 33 (1989) 6970.

${ }^{24}$ Por supuesto también B. Subercaseaux, ver nota 13.
} 
desde su complejo mundo psíquico o desde la crisis de las ideologías". ${ }^{25}$ Juan Andrés Piña agrega otros elementos, además de los señalados, como el uso del pastiche, de elementos populares, de "un lenguaje más visual que auditivo ..., más misterioso que evidente", rasgos que de acuerdo al crítico, marcarían la aparición de una "nueva estética que asomó en los ochenta" ${ }^{26}$ El cuestionamiento posmoderno de "los grandes relatos/discursos de la cultura" está igualmente presente en el siguiente comentario de Piña sobre La secreta obscenidad de cada dia:

La postura metafórica de la obra es delirante, aunque no incoherente: los dos pensamientos aquí representados - el individualista y el colectivista - han sido deformados y exacerbados de tal manera por la sociedad contemporánea, que convirtieron a esos dos pensadores en el sustento ideológico para oprimir a la sociedad. ${ }^{27}$

De lo expuesto pueden desprenderse las siguientes conclusiones parciales: (1) El discurso dramático de La secreta obscenidad de cada día se configura a partir de dos factores condicionantes, que no se invalidan sino que más bien se complementan: uno histórico/político, la dictadura chilena, y otro, estético/cultural que se relaciona con el paradigma posmoderno. (2) La ludicidad de la obra, sus juegos metaficticios y sentido plurivalente no son simples recursos para realzar el significante que fagocita el significado, sino que hay en ella una visión del mundo que se conecta a realidades implícitamente referidas. (3) Que la posmodernidad en Hispanoamérica presenta otras características que la del mero artificio y que podemos relacionar con lo que la crítica cubana Magaly Muguercia denomina posmodernismo progresista, en el cual además de las características formales que se podrían adscribir a la posmodernidad, no se prescinde "ni de la historidad, ni de una voluntad crítica radical, ni de una visión progresista" ${ }^{28}$

Estas mismas observaciones, como veremos, se aplican por igual a King Kong Palace, obra en la que nos centraremos a continuación.

\section{King Kong Palace: La desconstrucción de Tarzan y sus mitos culturales}

Soy un viejo jerarca derrotado. Y punto. Conocí la gloria, conocí el poder hasta la médula, me embriagué de él. Hoy conozco la derrota (19-20).

\footnotetext{
${ }^{25}$ María de la Luz Hurtado, "Presencia del teatro chileno durante el gobierno militar", Cuadernos Hispanoamericanos 482-83 (agosto-septiembre 1990) 156-157.

26 "La mirada desmitificadora", El público 78 (mayo-junio 1990) 126.

27 Juan Andrés Piña, "Pastiche y tragedia contemporánea en las obras de Marco Antonio de la Parra". Addendum a M.A. de la Parra, King Kong Palace o El exilio de Tarzán (Santiago, Chile: Pehuén, 1990) 161-162.

${ }^{28}$ Magaly Muguercia, "Antropología y posmodernidad", GESTOS 1115 (abril 1993) 19. Aunque la autora presenta esta alternativa como hipotética, creemos que ya es una realidad y que las obras de De la Parra son un buen ejemplo de ello.
} 
King Kong Palace es, entre las obras de Marco Antonio de la Parra, la más posmoderna. En ella el autor no sólo desconstruye un mito cultural más (esta vez un héroe mítico de ficción popular), sino que también hace un extensivo uso del pastiche, que es considerado por muchos críticos como un ícono de la cultura posmoderna. ${ }^{29}$ El empleo del pastiche definido aquí muy simplemente como la imitación de estilos (imágenes, motivos, expresiones linguísticas, personajes etc.) pertenecientes a otros textos-se anuncia desde el comienzo mismo de la obra: "Los cuatro actos ocurren en los gigantescos pasillos de un gran hotel, mezcla de todos los estilos imaginables ornamentados con toda la grandiosidad de la decadencia" (9). La imitación de estilos, no se limita, sin embargo, como pareciera sugerir esta cita, sólo a la decoración, en que predomina una atmósfera gótica con aire expresionista y de cuentos de Poe, sino que se extiende por igual a los personajes y sus discursos. En la obra se incorporan personajes conocidos de la cultura popular, provenientes de películas o de historietas, que emplean un registro de habla elevado que, por su estatuto semántico, no les corresponde. Se trata más bien de modos de habla propios de personajes de la tradición clásica e isabelina. Se crea así un juego metatextual en que resuenan figuras de Macbeth, Hamlet, Otelo, El Rey Lear, Romeo y Julieta, Sueños de una noche de verano o Edipo Rey. Fiel, por una parte, a los códigos del pastiche, que a diferencia del plagio, nunca niega el préstamo, $y$, por otra, a la modelización metaficticia -que por su reiterado uso puede considerarse como uno de los rasgos distintivos de su poética dramatúrgica- el autor sistemáticamente hace siempre visible la imitación alcanzada, técnica que le permite a su vez develar los mecanismos de la producción textual, del metateatro. Con el uso del pastiche, el autor no se propone componer un texto como "un mosaico de citas" (defecto que algunos críticos atribuyen al texto resultante de la imitación-pastiche), sino que obedece a una clara intención estética e ideológica. A través de la integración de códigos y registros provenientes de la cultura popular y de la elevada, De la Parra se propone borrar la tradicional línea demarcatoria que separa a los textos cultos de los populares, línea que, bien lo sabemos, ha sido arbitrariamente trazada a lo largo de la historia del arte. Tampoco se trata de un juego intrascendente de significantes: la concepción estructural de la obra está en perfecta sincronización con otra trasgresión de fronteras, pero ahora de carácter ideológico, la cual se configura en torno al mito de Tarzán y a los paradigmas culturales que lo sustentan, que De la Parra, en su estilo característico, desconstruye paródica y traviesamente. Este último punto será el tema central que desarrollaremos a continuación.

\section{El mito de Tarzan y sus paradigmas culturales}

Edgar Rice Burroughs publica su primer libro Tarzan of the Apes en 1912. Gracias al enorme éxito conseguido, se convierte en una serie de 26 libros, con 36 millones de copias, los cuales son traducidos a 30 lenguas y adaptados al cine, a la radio, televisión e historietas de diarios. En la serie, Borroughs narra episodio tras episodio las aventuras y hazañas del eternamente joven y musculoso Tarzán. Nos cuenta cómo, gracias a su inteligencia y fortaleza física (los dos rasgos imprescindibles del héroe épico), el sin par héroe logra

${ }^{29}$ La comparación se hace en base al ilimitado eclecticismo del posmodernismo que, en chillona consonancia, une los más dispares y contrastantes estilos. 
convertirse en jefe de los monos, vengar la muerte de su madre adoptiva, salvar a Jane de ser raptada por un gorila, coronarse rey de los wasuri, en fin, salir siempre airoso y triunfante de las innumerables empresas por las que lo hace pasar su autor. Sin embargo, el texto de más interés para nosotros (y suponemos que también para De la Parra) no es el de las aventuras y triunfos del héroe, sino el subtexto ideológico, los paradigmas culturales que subrepticiamente se imponen a lo largo de toda la serie de Burroughs y en las adaptaciones audiovisuales que le siguen. ${ }^{30}$

En Tarzán es posible percibir una ideología configurada en torno a la díada yo/otro, la cual se convierte en un eje estructurante al que se asocia una larga serie de pares antitéticos: humano/animal, hombre/mujer, blanco/negro, civilizado/salvaje, norte/sur, soberania nacional/colonialismo, dominante/dominado, opresor/oprimido, belleza/fealdad, inteligencia superior/inteligencia inferior, agresivo/pasivo, etc., que al combinarse y generar otras oposiciones, dan como resultado la creación de paradigmas culturales bastante nítidos. Borroughs, completamente imbuido de las ideas darwinistas (muy en boga en su época), no cree en el buen salvaje de la tradición romántica rousseauniana (como podría dar la impresión) sino que convierte a Tarzán en un prototipo de la raza humana que por su laborioso esfuerzo se eleva de un estado de salvajismo e ignorancia al de hombre civilizado. Este ascenso lo logra el héroe gracias a dos atributos heredados: a su inteligencia (la inteligencia proveniente de su ancestro europeo nórdico) y a su agresividad, que en su vida selvática no ha sufrido los efectos inhibidores de la civilización. Estos atributos le hacen superior a todos los habitantes de la selva africana, animales y humanos incluidos. La agresividad, como motivo, es de recurrente persistencia en Tarzán. En efecto, una lectura atenta nos lleva fácilmente a inferir que Burroughs parte de un presupuesto básico: que todas las especies son igualmente agresivas y que los europeos no son mejores o peores que los africanos en esta cualidad. La superioridad de los nórdicos se debe a que son más inteligentes y a que tienen acceso a mejores ideas y a una tecnología más avanzada. De este modo, en Tarzán se postula una ideología de base racista y genética en que animales, africanos, europeos del sur, europeos del norte, forman una jerarquía cuyo factor determinante es la inteligencia heredada. Esto explica que al salvar Tarzán a Jane no la viole sino que, de acuerdo al paradigma europeo y no al primordial, la trate cortésmente: su gen europeo se activa aún antes de ser expuesto a la cultura occidental. Es interesante notar también que hasta este episodio, aunque ha tenido la oportunidad, Tarzán no ha mostrado ningún interés por una mujer negra. Su atracción al sexo opuesto sólo se despierta al encuentro de la mujer rubia y blanca, es decir, al descubrir la pareja que le corresponde por "naturaleza". Por su parte, Terkoz - un mono descastado de la tribu de Tarzán — al descubrir a Jane y su sirvienta Esmeralda, su atracción inmediata no es hacia la negra sino hacia la blanca. Como bien lo sostiene Torgovnick, ${ }^{31}$ esta escena refleja la realidad cul-

${ }^{30}$ Desde ahora con el término Tarzán nos referiremos a toda la serie.

${ }^{31}$ Muchas de las ideas expresadas en esta sección provienen de: Marianna Torgovnick, Gone Primitive : Savage Intellects, Modern Lives (Chicago y Londres: The University of Chicago Press, 1990). Véase en especial el capítulo "Taking Tarzan seriously". Otras fuentes fueron: Antony Easthope, Literary into Cultural Studies (Londres y New York: Routledge, 1991) y Eric Cheyfitz, The Poetics of Imperialism: Translation and Colonization from The Tempest to Tarzan (New York/Oxford: Oxford University Press, 1991). 
tural de Burroughs en la cual el entrecruzamiento racial no era permitido. No era (y para muchos todavía no lo es) imaginable/aceptable que un varón blanco buscara como pareja a una negra. En cambio, sí era posible que un negro sintiera atracción hacia una blanca: la raza superior siempre es un bien deseado. Hay implícito en Tarzán el peligro que significa el entrecruzamiento racial, que en dicho episodio está disfrazado (para que resulte más aberrante) como entrecruzamiento de especie (mono/humano, Terkoz/Jane).

Gracias a la inteligencia y virtud heredadas, y a su agresividad no reprimida, Tarzán se convierte en rey de los antropoides (poder que conquista compensando su pequeñez con la tecnología), y luego en rey de los waziri, que en la escala evolutiva son superiores todos negros, sobre todo a los de la tribu de Kulonga, ${ }^{32}$ que son descritos, para resaltar su bestialidad, como caníbales y de un físico parecido a los gorilas. En cambio, los waziri, si no fuera por su color, podrían perfectamente pasar por europeos. Los waziri, han elegido a Tarzán como su rey, para lo cual han seguido el proceso de selección natural: lo han nombrado su jefe, porque entre todos es el mejor. Pero a medida que Tarzán va conociendo mejor las leyes del mundo occidental, va cambiando notablemente el sistema social y económico de la tribu, la cual es convertida finalmente en un paraíso feudal perdido en el corazón de África. Consecuentemente, los waziri son trasformados en leales servidores que cocinan, limpian, cuidan el jardín y cultivan la tierra. Este trastorno social está claramente signado sociolingüísticamente, en el modo con que Tarzán empieza a apelar a los negros. Ahora son para él "my boys", es decir, sus subordinados y, peor aun, parte de su propiedad. De este modo, la tribu africana que era presentada como modelo africano ideal, se ha convertido en un grupo de siervos domésticos y en cargadores de zafaris. Tarzán ya no es más el jefe elegido por el respeto y admiración. La relación que ahora rige entre él y los negros es la de dominante/dominado, dueño/sirviente. La secuencia lógica del paradigma cultural impuesto se proyecta fácilmente hacia lo que era futuro para Burroughs y lo que es un presente real para los lectores/espectadores de King Kong Palace: sistema tribal $\rightarrow$ sistema feudal $\rightarrow$ capitalismo $\rightarrow$ ¿neocapitalismo/neoliberalismo?

Una lectura del subtexto de la serie de Tarzán nos revela un África descrita en los términos siguientes: (1) como un continente sin historia, es decir, como una sociedad primitiva, estacionaria en un eterno presente, que correspondería a un remoto pasado de la historia occidental. El Occidente, por contrapartida, sí tiene una historia, cuyos pasos deben ser seguidos por las sociedades primitivas (¿tercermundistas?). Se crea así la falsa impresión de que África no tuvo civilización, que ésta llegó desde Europa, desde los blancos. Esta última idea es reforzada (a través del motivo de "la ciudad perdida") con el hallazgo de esplendorosas ciudades perdidas en la selva que, por supuesto, en un ignoto pasado habían sido construidas por blancos. (2) A través de una metáfora falocéntrica, África es descrita como un cuerpo de mujer "para ser invadido, conquistado y sus riquezas cosechadas y gozadas". ${ }^{33}$

La serie Tarzán está dirigida a un receptor masculino al cual se le ofrece un protagonista modelo, con todos los atributos del hombre ideal: fuerte, inteligente, agresivo, emprendedor, anglosajón (blanco y rubio). Gracias a su inteligencia, Tarzán aprende a leer solo. Es

\footnotetext{
${ }^{32}$ Tarzán mata a Kulonga para vengar la muerte de su madre adoptiva perpetrada por éste.

${ }^{33}$ Torgovnick, Gone Primitive 61.
} 
importante observar que las primeras palabras que aprende de los libros ilustrados que encuentra en la cabaña en que vivieran sus padres son hombre, arquero negro, palabras en las que, junto con las que aprende en su primer encuentro con Jane: "Yo Tarzán, tú Jane", están los rasgos semánticos esenciales que lo designan y signan en su futuro de "hombre civilizado": hombre/mujer, blanco/negro, macho/hembra, fuerte/débil, activo/pasivo.

El signo mujer, por otro lado, se construye a partir de los atributos opuestos a los masculinos. Aquellas mujeres que como la reina $\mathrm{La}$ (la del matriarcado de Opar) osen (como las Amazonas) trasgredir el paradigma genérico que les corresponde de acuerdo al patrón occidental, deben ser encauzadas y puestas en el lugar que les corresponde, y si se resisten al cambio, hay que matarlas. Jane representa a la mujer que puede ejercer un cierto control en el único espacio que le pertenece, el mundo doméstico. Pero, paradójicamente, éste es también el espacio donde Jane a su vez "domestica", es decir "civiliza" a Tarzán, despojándolo (la mujer castradora) de su naturaleza vital. Al atar los cabos de lo expuesto, si tenemos en mente el ensalzamiento de la cultura nórdica y del varón, la imagen falocéntrica de África, el estado en que terminan los waziri, la mujer, jerárquicamente, es puesta en un nivel paralelo al continente africano y a sus habitantes. ${ }^{34}$

En conclusión, la ideología subyacente en el mito Tarzán es clara. El sistema de valores que se propone como modelo es el occidental (particularmente el anglosajón), es decir, el paradigma patriarcal, capitalista, colonialista y racista que lo caracteriza. Recordemos aquí lo sostenido por Frye ${ }^{35}$ que las sociedades cambian de rumbo y de sistema de valores (ideologías) mediante un doble proceso: primero se inventan los mitos y leyendas que dan forma a la sociedad ideal; segundo, los mitos y leyendas se convierten en acción. En las postrimerías del siglo XX, el mito Tarzán (con otros ropajes y transmitido ahora via satélite) sigue aún vigente y avanza inexorablemente hacia todos los puntos cardinales y con él el neoliberalismo: "Nada como una mente llena de leyendas para ser fácilmente dominado" (21), sostiene Tarzán en King Kong Palace. ${ }^{36}$

\section{El exilio de Tarzán o el jerarca derrotado}

Al comienzo de King Kong Palace, De la Parra previene a los actores: "La actuación debe evitar a toda costa la parodia" (9). A pesar de esta acotación y aun cuando en la escenificación de la obra los actores la sigan fielmente, King Kong Palace es un texto paródico por excelencia. La parodia (como lo ha dejado muy en claro Bakhtin) consiste en un doble discurso, ${ }^{37}$ en que uno toma como objeto a otro ya existente y lo asume imprimiéndole una orientación opuesta. Esta operación hace que los dos discursos no sólo

\footnotetext{
${ }^{34}$ Torgovnick, 61 .

${ }^{35}$ Northrop Frye, Myth and Metaphor (Charlottesville y Londres: University of Virginia Press, 1990). Ver en especial el capítulo "Framework and Assumption", 79-83. También ver William G. Doty, Mithography: The Study of Myths and Rituals (Alabama: University of Alabama Press, 1986).

${ }^{36}$ Aunque tiene el cuidado de rectificarse, inmediatamente, agregando: “Ojo, esa frase no es mía, es de mi mujer" (21).

${ }^{37}$ Estos discursos, según la terminología de Genette, corresponderían al hipotexto y al hipertexto, respectivamente. Gérard Genette, Palimpsestos (Madrid: Taurus, 1989).
} 
se distancien, sino que se confronten en franca hostilidad. La parodia, según Fowler, "busca por medio de la imitación subversiva, toda debilidad, pretensión o falta de autoconciencia del original". ${ }^{38}$ Al comparar King Kong Palace y Tarzán salta a la vista que los dos textos están en abierta confrontación. No sólo porque se degrada al siempre joven y triunfante protagonista, sino especialmente porque se hacen abiertamente visibles todos los soterrados mecanismos ideológicos que el texto de Burroughs cuidadosamente oculta. En efecto, aunque el autor estadounidense nos presenta a un narrador que en ocasiones verbaliza su oposición al colonianismo y a los prejuicios raciales, a través de su relato no hace más que reforzar los paradigmas culturales firmemente arraigados en él. En King Kong Palace, De la Parra desconstruye el discurso de Burroughs poniendo al descubierto su subyacente y escamoteada ideología. El Tarzán de King Kong Palace es un Tarzán actualizado, contextualizado históricamente, con una "vestidura" (¿máscara?) contemporánea, es un dictador que ha sido destituido y expulsado con su mujer al exilio. Ambos han llegado al King Kong Palace, un hotel de hostil diseño gótico donde viven, como especie de fantasmas, un administrador, tres camareras y Mandrake el mago. Se trata de un espacio hermético, oscuro y asfixiante, diametralmente opuesto al abierto, luminoso y vivificante de la selva africana. Los personajes que allí pululan parecen en perfecta consonancia con la atmósfera de decadencia que se respira. Decadentes son Tarzán y Jane, las viejas camareras y Mandrake, que de paladín de la justicia en las célebres historietas, está reducido a animador de cumpleaños infantiles y de "shows baratos en la televisión" (48). No resulta sorprendente que los motivos más persistentes que dan sentido a este abigarrado mundo sean "la nostalgia", la "lamentación por el poder perdido" y "el vano deseo de recuperarlo". Aunque derrotado y expatriado, Tarzán no busca sin embargo un retorno al pasado, el cual al mismo tiempo que añora, lo rechaza. Su viaje ahora no es el exterior, como el que lo llevaba a recónditas tierras e increíbles aventuras, sino que es un viaje hacia la interioridad del ser, un viaje de autorreconocimiento, de autoexamen. Su precaria y lamentable figura del comienzo se va haciendo, a medida que la obra avanza, más y más digna y profunda hasta transformarse en un personaje de la altura moral, como el requerido por el género trágico. Es un Tarzán que inmerso en las tinieblas de la ceguera, se convierte en la voz contrapuntística del discurso autoral de Burroughs, al ir demoliendo sistemáticamente todos los paradigmas culturales que su propia figura ayudara a construir en el texto parodiado. Su último deseo es lograr el perdón de su hijo, que convertido en un fantasma deambula en el hotel, esperando el momento para enfrentar a su padre. Pero mientras Tarzán busca el perdón de su hijo, éste lo que persigue es la venganza. Aunque Jane diga lo contrario, Tarzán fue el causante de la muerte de su hijo al ordenar a la policía que atacara a los nativos amotinados, entre los cuales, solidario con los negros, se encontraba el adolescente. En vez del perdón, lo que Tarzán consigue (como Edipo) es la ceguera.

Jane, si bien es un personaje paródico que raya casi en lo caricaturesco, es en otro sentido, el menos paródico, puesto que tanto en Tarzán como en King Kong Palace, aparece con los mismos rasgos: como la portadora y defensora del paradigma colonialista. Lo que ha cambiado es su rol actancial: de sujeto de enunciado en Tarzán, es decir, de personaje

${ }^{38}$ Roger Fowler, ed., A Dictionary of Modern Critical Terms (London: Routledge and Kegan Paul, 1990). Edición revisada (la traducción es nuestra). 
que en su accionar encarnaba el paradigma occidental, ha devenido, en la obra de De la Parra, sujeto de enunciación, o sea, el personaje que verbaliza y pondera dicho paradigma. El estatuto simbólico que Jane representaba en la obra original y que se expresaba en la fórmula: Jane, la niña de Baltimore = civilización anglosajona, en King Kong Palace se muestra y despliega en toda su magnitud. En sus amargos parlamentos, Jane nos va relatando cómo su más importante tarea fue la de enseñar a Tarzán el arte de gobernar de acuerdo a la tradición occidental, a la de "Julio César", "Napoleón”, “Alejandro el Magno" (33-34). Arte que puntualiza en una larga lista que resumimos: (1) desprecio por nativo. Los negros son "monos negros", "inferiores"(32), "imbéciles"(66). (2) Ejercicio una mano dura. Mientras más represivo y cruel es el gobierno, tanto mejor. "Nuestro momento más feliz fue cuando eras cruel e implacable ... Hasta los caníbales nos respetaban ...(34) "Eras inmensamente cruel, eras visionario, eras fanático ... Casi perfecto" (31). (3) Imposición del miedo como la forma de control más efectiva. "[Hay que] dejar el miedo a los dominados, no al dominante". (4) El asesinato se justifica en aras del progreso. "La civilización es crueldad ... Sólo la guerra es conquista" (33). Tarzán resulta un excelente discípulo (pareciera que en él se reactivan los valores que cargaba en sí genéticamente). A propósito de este rápido aprendizaje, lo increpa Jane:

... Bastó que te enseñara a hablar y te convertiste en orador ... Que te leyera un tratado de historia y te autonombraste general ... Un par de artículos de revista y eras economista neoliberal ... Tu primer gabinete eras tú mismo en todos los ministerios (31).

La dictadura empieza a flaquear cuando Tarzán decide compartir el poder, educar a sus súbditos y crear industrias, todo lo cual culmina con la rebelión y su consecuente exilio. En pasajes como el citado, la intencionalidad paródica de King Kong Palace, se desvía de la relación intertextual y se torna más bien satírica al situarse en un referente histórico social actualizado: el de las dictaduras y falsas democracias nacionales e internacionales.

El personaje Mandrake, el mago bueno de antaño, es ahora un personaje corrompido (estado al que llega, como se verá, inducido por el administrador). Como Jane, desea recuperar el poder perdido, pero esta vez para ser usado malévolamente. Su ardiente deseo es suplantar a Tarzán, empaparse de su gloria. Con el fin de cumplir su cometido pone sus ojos en Jane, que tan ambiciosa como él, se deja seducir rápidamente, no con sus propuestas amorosas sino movida por la misma ansia de poder que los hermana. Sus siniestros planes que les llevan al asesinato de Tarzán, culminarán con su propia destrucción.

La obra termina "cuasi operáticamente" 39 en un vertiginoso desenlace: Mandrake mata a Jane y el administrador liquida a Mandrake. Las imágenes de sangre y horror dominan la escena final, en la cual se yergue e impone la figura del administrador, que hasta entonces había aparecido sólo furtivamente, aunque siempre sospechoso y enigmático. Es ahora cuando desenmascara sus oscuros móviles: Tarzán, Jane y Mandrake no eran sino potenciales títeres, que serían usados para implantar un gobierno represivo en que los

\footnotetext{
${ }^{39}$ El subtítulo de la obra es (Obra operática en cuatro actos).
} 
últimos beneficiarios serían el administrador y el grupo social a quien representaba. ${ }^{40}$ Pero los candidatos no han calificado para el trabajo, pues se han dejado llevar por las pasiones: "[No son la] gente dura, firme, implacable", el "cuchillo sereno y riguroso que pusiera orden" (91).

La obra termina con vidrios que empiezan a romperse, mientras el administrador solitario toca el piano impasible. El desenlace no es circular como el de Los invasores de Egon Wolff (cuya reflexión intertextual se capta aquí), sino en forma de una espiral que anuncia acontecimientos similares a los que llevaron a Tarzán y Jane al destierro: hay un motín que se avecina en contra del poder represivo. La historia se repetirá, pero con nuevos protagonistas. Tiene que ineludiblemente repetirse, porque bien lo dice el Tarzán de King Kong Palace, no el de Burroughs por supuesto: "No se puede hacer crecer a alguien esperando que se someta para siempre".

La crítica es unámine en señalar a Marco Antonio de la Parra como el dramaturgo más innovador del teatro chileno de las últimas décadas. La originalidad y creatividad de las obras estudiadas en este artículo confirman tal consenso. Aunque el autor renuncia definitivamente a la convención realista, al teatro didáctico de mensaje directo y sociológico, como lo hemos intentado demostrar, sus obras reflejan una constante preocupación por el contexto sociocultural contemporáneo. Mediante el uso de recursos propios de la convención posmoderna (metateatro, descentramiento, ludicidad, fragmentación, polisemia, ambivalencia) y del empleo de entrelazadas ondas isotópicas (mito, ritual, poder), el autor se interna en las profundidades del ser humano para descubrir sus inherentes contradicciones, las irreconciliables polarizaciones que en él subyacen, y que se reflejan en su entorno cultural y social, en sus visiones del mundo, en sus mitologías. A partir de una ludicidad profundamente seria, con que juguetonamente hace explotar afincados patrones y fronteras, y a través del cuestionamiento y revisión de los grandes paradigmas culturales, el autor, al mismo tiempo que nos devela la complejidad de la realidad humana y social, crea un nuevo discurso dramatúrgico, una nueva estética teatral. Efectivamente, con él: una nueva dramaturgia estira sus alas.

\footnotetext{
40 "He leído en su mirada - le dice Mandrake - que necesitaba criminales francos y directos ... Lo he escuchado hablar de la crueldad necesaria para quien ejerza el poder, de la debilidad de aquellos que insisten en vanas teorías morales, de la urgencia de una mano firme, de un liderazgo implacable, de un pulso que no tiemble ..." Replica el administrador: "Pensamos en ti como el héroe que alguna vez conocimos, creímos que podrías salvarnos, que podrías venir al King Kong Palace y ser el cuchillo sereno y riguroso que pusiera orden" (91).
} 